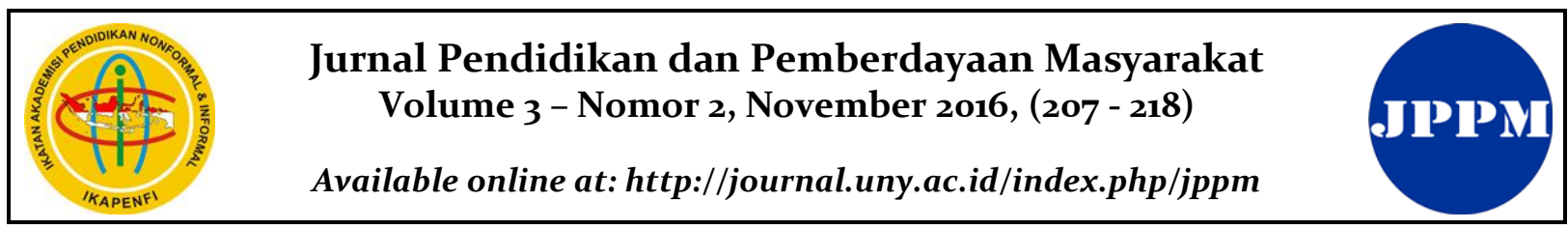

\title{
PENINGKATAN PERKEMBANGAN KOGNITIF ANAK USIA DINI MELALUI MEDIA BERMAIN MEMANCING
}

\author{
Wulandari Retnaningrum \\ Universitas Nahdlatul Ulama Ghonzali. Jalan Kemerdekaan Barat No.17, Kesugihan Kidul, \\ Kabupaten Cilacap, Jawa Tengah 53274, Indonesia \\ Korespondensi Penulis. Email: wulandari.retnaningrum@yahoo.com, Phone: (+62282) 695407
}

\begin{abstract}
Abstrak
Penelitian ini bertujuan untuk mengetahui proses dan hasil pembelajaran sebagai upaya meningkatkan perkembangan kognitif anak melalui media bermain memancing pada anak kelompok B di TK Miftahul Huda, Kabupaten Cilacap. Jenis penelitian ini adalah Penelitian Tindakan Kelas (PTK). Penelitian ini menggunakan desain Kemmis dan Mc Taggart. Setiap siklus terdiri atas empat tahap yaitu: perencanaan, pelaksanaan tindakan, observasi, dan refleksi. Subjek penelitian adalah anak kelompok B TK Miftahul Huda. Teknik pengumpulan data dilakukan melalui observasi, wawancara dan studi dokumentasi. Data yang terkumpul dianalisis secara diskriptif kualitatif dan kuantitatif. Hasil penelitian menunjukkan perkembangan kognitif anak sebelum tindakan masih dalam kategori mulai berkembang yakni $58,55 \%$; hasil penelitian siklus I mencapai $69,62 \%$ dalam kategori berkembang dan siklus II mencapai 8o,99\% dalam kategori sangat berkembang; penggunaan media bermain memancing mempunyai dampak sangat baik ditunjukkan dengan perkembangan kognitif anak yang mengalami perkembangan sangat baik dibandingkan sebelum tindakan
\end{abstract}

Kata Kunci: perkembangan kognitif, anak usia dini, media bermain memancing.

\section{IMPROVING EARLY CHILDHOOD COGNITIVE DEVELOPMENT THROUGH FISHING GAMES}

\begin{abstract}
This study aims to know the process and result of the lesson to improve cognitive development through fishing games for group B children of kindergarten Miftahul Huda Cilacap District.This research was a kind of classroom action research.This study used the Kemmis and Taggart's design. Each cycle consists of four phases: planning, action, observation, and reflection. The research subjects are group B children of Kindergarten Miftahul Huda. The data collection techniques included observation, interviews, and documentation study. The collected data were analyzed using descriptive qualitative and quantitative methods. The results of the study show that the cognitive development of child before the action is still in the category of beginning to developing, that is 58,55\%; the results first cycle reaches $69,62 \%$ in the category of developing and the second cyclereaches $80,99 \%$ in a category of highly developed; the use of fishing games has a very good impact on cognitive development shown by the cognitive development of the children, which is higher after the action compared to that before the action.
\end{abstract}

Keywords: cognitive development, early child, fishing game.

How to Cite: Retnaningrum, W. (2016). Peningkatan perkembangan kognitif anak usia dini melalui media bermain memancing. Jurnal Pendidikan dan Pemberdayaan Masyarakat, 3(2), 207-218. doi:http://dx.doi.org/10.21831/jppm.v3i2.11284

Permalink/DOI: http://dx.doi.org/10.21831/jppm.v3i2.11284 


\section{Jurnal Pendidikan dan Pemberdayaan Masyarakat, 3 (2), November 2016 - 208 \\ Wulandari Retnaningrum}

\section{PENDAHULUAN}

Perkembangan berbagai aspek anak berjalan secara holistik, tidak terjadi secara terpisah dan dipengaruhi oleh berbagai faktor internal dan eksternal. Faktor internal adalah berbagai aspek perkembangan yang dimiliki anak, faktor eksternal adalah keluarga, guru, dan berbagai sumber belajar yang lainnya.

Anak sejak lahir sampai usia 6 tahun merupakan pondasi awal bagi pertumbuhan dan perkembangan anak selanjutnya. Pada usia ini pertumbuhan fisik dan perkembangan mental anak terjadi sangat pesat. Sekalipun Tuhan telah memberikan potensi bawaan pada anak, lingkungan memberikan sikap, kepribadian dan pengembangan pembelajaran anak. Setiap anak bersifat unik yang terlahir dengan potensi yang berbedabeda, memiliki kelebihan, bakat dan minat sendiri-sendiri yang perlu dikembangkan melalui proses pendidikan.

Bentuk pendidikan untuk anak usia empat sampai enam tahun adalah pendidikan Taman Kanak-kanak yang merupakan pendidikan pada jalur pendidikan formal. Undang-Undang Nomor 20 Tahun 2003 tentang Sistem Pendidikan Nasional pasal 1 ayat 14 menyatakan bahwa "Pendidikan anak usia dini adalah suatu upaya pembinaan yang ditujukan kepada anak sejak lahir sampai dengan usia enam tahun yang dilakukan melalui pemberian rangsangan pendidikan untuk membantu pertumbuhan dan perkembangan jasmani dan rohani agar anak memiliki kesiapan dalam memasuki pendidikan lebih lanjut" (Pusat Kurikulum Direktorat PAUD, 2007, p.5).

Salah satu aspek kemampuan dasar anak yang perlu dikembangkan yang akan sangat berpengaruh terhadap pertumbuhan dan perkembangan pada aspek lain adalah perkembangan kognitif. Mena \& Eyer (2009, p.175) mengemukakan perkembangan kognitif menjadi perhatian karena berhubungan dengan keterampilan, memori, bahasa dan kemampuan memecahkan masalah.

Perkembangan kognitif adalah perubahan yang terjadi dalam berpikir, kecerdasan dan bahasa anak untuk memberikan alasan sehingga anak dapat mengingat, menyusun strategi secara kreatif, berpikir bagaimana cara dapat memecahkan masalah dan dapat menghubungkan kalimat menjadi pembicaraan yang bermakna (meaningfull) (Sujiono, 2014, p.1.7).

Perkembangan kognitif usia 3 sampai 6 tahun berada pada tahap praoperasional yaitu (1) Menggunakan simbol, dimana anak tidak harus kontak sensorimotor dengan objek. Anak dapat membayangkan objek atau orang tersebut memiliki sifat yang berbeda dengan yang sebenarnya; (2) Memahami identitas, dimana anak memahami bahwa perubahan yang terjadi tidak merubah karakter ilmiah; (3) Memahami sebab akibat, dimana anak memahami bahwa suatu peristiwa ada sebabnya, (4) Mampu mengklasifikasi, anak mengelompokkan objek, orang, suatu peristiwa ke dalam kategori yang bermakna, (5) Memahami angka, dimana anak dapat menghitung dan memahami angka Karakteristik perkembangan kognitif tahap pra-operasional antara lain: mengelompokkan benda yang memiliki persamaan, menghitung 1-20, mengenal bentuk-bentuk sederhana, memahami konsep makna berlawanan, mampu membedakan bentuk lingkaran atau persegi dengan objek nyata atau gambar, memasangkan dan menyebutkan benda, mencocokkan bentuk-bentuk sederhana, mengklasifikasikan angka, tulisan, buah dan sayur, mengenal huruf kecil dan besar, mengenal warna-warna. (Sujiono, 2014, p.2.16).

Perkembangan kognitif sangat penting dan sangat diperlukan bagi anak karena (1) mengembangkan daya persepsinya berdasarkan apa yang dilihat, didengar dan dirasakan agar anak dapat memahami dan menerima dengan baik, (2) melatih ingatannya pada peristiwa dan kejadian yang pernah dialaminya, (3) mengembangkan pemikirannya untuk menghubungan satu peristiwa dengan peristiwa yang lain, (4) menalar apa yang sedang terjadi baik proses alamiah (spontan) maupun proses ilmiah (percobaan), (5) memecahkan persolan hidup yang dihadapinya agar dapat menolong dirinya sendiri, (6) memahami berbagai simbol yang tersebar di lingkungan sekitarnya (Sujiono, 2014, p.1.25).

Pembelajaran perkembangan kognitif anak merupakan hal yang sangat penting, 


\section{Jurnal Pendidikan dan Pemberdayaan Masyarakat, 3 (2), November 2016 - 209}

Wulandari Retnaningrum

perlu mendapatkan perhatian yang sungguhsungguh, perlu dirangsang dan dikembangkan supaya anak dapat memecahkan masalah, membantu anak mengembangkan logika matematika, mengelompokkan dan mengetahui ukuran benda, maka hendaknya dalam mengarahkan anak melalui proses pembelajaran yang bermakna dan dilakukan secara sederhana melalui media. Media sebagai pesan apa yang akan dipelajari supaya memudahkan anak belajar memahami sesuatu yang mungkin sulit atau menyederhanakan sesuatu yang kompleks sehingga kegiatan pembelajaran menjadi lebih menarik, interaktif, menyenangkan dan kualitas pembelajaran dapat ditingkatkan.

Pendekatan kegiatan pembelajaran harus sesuai dengan dunia anak yaitu menggunakan media bermain sebab aktivitas anak tidak dapat dipisahkan dengan kegiatan bermain. Penggunaan media bermain akan lebih efektif, lebih menarik, menyenangkan, mudah diikuti dan dipahami karena bermain merupakan wahana belajar dan anak mendapatkan pengalaman sehingga potensi yang dimiliki dapat berkembang. Mulyasa (2014, p.191) mengatakan ketika bermain, anak mengungkapkan keinginan, pemikiran, perasaan, dan menjelajahi lingkungannya, serta menjalin hubungan sosial dan mengembangkan kemampuan sosial, kognitif, spiritual, moral, emosional secara bersamaan. Piaget mengemukakan bahwa bermain merupakan kebutuhan anak, dapat menimbulkan rasa senang, memberikan kesempatan untuk bereksplorasi, menemukan dan menggunakan benda-benda yang ada di sekitarnya, mengekspresikan perasaan, berkreasi dan belajar secara menyenangkan serta mendapatkan pengetahuan baru. Dengan proses bermain, pembelajaran menjadi sangat menyenangkan bagi anak. (Wijaya, 2009, p.1.31).

Media bermain yang tepat, menarik dan efektif digunakan dalam pembelajaran untuk meningkatkan perkembangan kognitif anak salah satunya menggunakan media bermain memancing agar perkembangan kognitif anak optimal. Hasil penelitian yang telah dilakukan oleh Ni Wayan Desi Mariani, Desak Putu Parmiti dan I Nyoman Wirya mengenai "Penerapan Metode Bermain Berbantu Media Kolam Pancing untuk
Meningkatkan Perkembangan Kognitif dalam Mengenal Lambang Bilangan" menunjukkan bahwa metode bermain dengan menggunakan media kolam pancing memancing lambang bilangan dapat meningkatkan pembelajaran perkembangan kognitif dalam mengenal lambang bilangan pada anak kelompok A2 semester II di TK Saiwa Dharma Singaraja tahun pelajaran 2013/2014.

Penelitian yang dilakukan Ni Made Rai Pradnya Sari, Ni Ketut Suarni, Didith Pramunditya Ambara mengenai "Penerapan Metode Drill Berbantuan Media Kotak Pancing untuk Meningkatkan Kemampuan Kognitif Anak" menunjukkan penerapan metode drill berbantu media kotak pancing dapat meningkatkan kemampuan kognitif anak kelompok A semester II tahun ajaran 2013/2014 di TK Widia KumaraPadangbulia. Metode drill adalah suatu cara menyajikan bahan pelajaran dengan jalan melatih anak secara terus menerus agar menguasai pelajaran dan memperoleh suatu keterampilan.

Media bermain memancing belum pernah digunakan dalam kegiatan pembelajaran di TK Miftahul Huda, Kabupaten Cilacap. Pembelajaran masih menggunakan LKA, bersifat hafalan sehingga perkembangan kognitif anak belum optimal dan belum sesuai dengan lingkup perkembangan kognitif yang harus dicapai pada tingkat pencapaian perkembangan kognitif usia 5-6 tahun yaitu (1) pengetahuan umum dan sains, (2) konsep bentuk, warna, ukuran dan pola, (3) konsep bilangan dan lambang bilangan.

Permasalahan yang terkait dengan perkembangan kognitif dalam penelitian ini adalah: (1) Bagaimana proses peningkatan perkembangan kognitif melalui media bermain memancing bagi anak kelompok B di TK Miftahul Huda Kabupaten Cilacap? (2) Bagaimana hasil pembelajaran menggunakan media bermain memancing pada perkembangan kognitif anak kelompok B di TK Miftahul Huda Kabupaten Cilacap?

Penelitian ini difokuskan pada masalah yang berkaitan dengan perkembangan kognitif dari aspek mengenal sebab akibat tentang lingkungan, membedakan konsep berat ringan, mengklasifikasikan benda berdasarkan ukuran, konsep bilangan dan lambang bilangan. 


\section{Jurnal Pendidikan dan Pemberdayaan Masyarakat, 3 (2), November 2016 - 210 \\ Wulandari Retnaningrum}

Penelitian ini bertujuan untuk mengetahui proses dan hasil pembelajaran sebagai upaya meningkatkan perkembangan kognitif anak melalui media bermain memancing. Media bermain memancing dapat meningkatkan perkembangan kognitif anak karena (1) bersifat konkret, anak dapat melihat benda secara nyata dalam bentuk tiruan sehingga anak tidak salah dalam membayangkan bentuk suatu benda, (2) meningkatkan kemampuan anak dalam mengenal sebab akibat, (3) hasil memancing anak mengenal perbedaan ukuran, mengklasifikasi, membilang 1-10 dan mencocokkan bilangan dengan lambang.

Penelitian ini diharapkan mempunyai manfaat teoritis yaitu hasil penelitian diharapkan dapat memberikan sumbangan ilmiah berupa data hasil penelitian dengan teori perkembangan kognitif untuk usia 5-6 tahun khususnya tentang peningkatan perkembangan kognitif melalui media bermain memancing.Manfaat praktis bagi anak untuk (1) meningkatkan perkembangan kognitif mengenai mengenal sebab akibat tentang lingkungan, membedakan konsep berat ringan, mengklasifikasikan benda berdasarkan ukuran, konsep bilangan, dan lambang bilangan dengan menggunakan media bermain memancing dan (2) memberikan pengalaman belajar yang unik dan menarik dengan menggunakan media yang konkret sehingga anak terlibat langsung dalam proses pembelajaran. Bagi guru (a) sebagai sumbangan pemikiran terhadap dunia pendidikan dalam upaya meningkatkan perkembangan kognitif melalui media bermain memancing, (b) meningkatkan dan memotivasi kreativitas dalam mengembangkan dan menggunakan media pembelajaran yang menarik, (c) dapat mengefektifkan proses belajar mengajar dalam rangka meningkatkan perkembangan kognitif, khususnya dengan menggunakan media bermain memancing, dan (d) meningkatkan profesionalisme guru.

Anak akan lebih memahami apa yang dipelajari dalam kegiatan pembelajaran dengan menggunakan media bermain. Dikemukakan oleh Huang (2013, p.11) bahwa anak bermain menggunakan media bermain sebagai proses kognitif dan sebagai alat untuk menambah pengetahuan. Pembelajaran menggunakan media bermain memancing membuat anak dapat melakukan percobaan, memahami sesuatu, membangun pengertian sendiri dan menemukan pengalaman bermakna bagi anak (Pusat Kurikulum Direktorat PAUD, 2007, p.7). Goldstein (2012, p.11) mengatakan anak melalui bermain mulai belajar keterampilan matematika seperti menghitung, kesetaraan, penambahan dan pengurangan, estimasi, perencanaan, pola, klasifikasi, volume dan luas, dan pengukuran untuk memberikan dasar formal membangun matematika.

Anak bermain menggunakan media memancing akan mendapatkan pengalaman langsung sehingga dapat meningkatkan hasil belajar. Hal ini sesuai dengan pendapat Benson \& Odera (2013, p.1) bahwa pemilihan dan penggunaan media diharapkan dapat memainkan peran penting dalam meningkatkan kinerja akademik.

Semakin banyak pengalaman yang diperoleh anak maka semakin berkembang pula struktur kognitifnya. Hal ini sesuai pendapat bahwa anak harus belajar dengan fisik memanipulasi bahan dan mengintegrasikan pengalaman untuk pengalaman kehidupan nyata (Bernard \& Olivia, 1994, p.82). Brewer (2007,p.353) mengatakan bahwa guru harus melibatkan anak secara fisik dan mental dalam berpikir reflektif dengan cara mengajukan pertanyaan apa yang anak amati dan kemudian membimbingnya. Santrock (2007, p.5o) mengemukakan pengalaman dan pengetahuan yang diperoleh anak tidak lepas dari interaksi sosial anak dengan orang dewasa serta teman sebaya. Feldman (2009, p.359) mengatakan anak belajar dengan cara menginternalisasi hasil dari interaksi-interaksi dengan orang dewasa dengan membantu anak melewati Zone of Proximal Development (ZPD), kesenjangan antara apa yang sudah bisa mereka lakukan dengan apa yang belum bisa mereka capai dengan mengandalkan diri mereka sendiri. Dimensi proses pembelajaran menggunakan media bermain dapat membantu anak mendapatkan pengalaman berharga dengan langsung terlibat aktif pada aktivitas pembelajaran sehingga meningkatkan perkembangan kognitif dan kinerja akademik anak. 


\section{Jurnal Pendidikan dan Pemberdayaan Masyarakat, 3 (2), November 2016 - 211 \\ Wulandari Retnaningrum}

\section{METODE}

Penelitian ini merupakan Penelitian Tindakan Kelas (PTK) atau Classroom Action Research(CAR). PTK bercirikan perbaikan terus menerus sehingga kepuasan peneliti menjadi tolak ukur berhasilnya siklus tersebut. Penelitian tindakan kelas melalui proses yang dinamis dan saling melengkapi dengan beberapa tahapan: perencanaan (planning), pelaksanaan tindakan (action), observasi (observation), dan refleksi (reflection).

Pada tahap perencanaan, peneliti berkolaborasi dengan guru kelas melakukan perencanaan penelitian sebagai berikut: (a) menyiapkan Rencana Kegiatan Harian (RKH) yang berisi tentang materi kegiatan pembelajaran, (b) menyiapkan media pembelajaran yang akan digunakan yaitu media bermain memancing, (c) menyiapkan lembar observasi sebagai pedoman penilaian untuk melihat peningkatan perkembangan kognitif anak.

Pelaksanaan tindakan dilaksanakan berdasarkan perencanaan. Pelaksanaan bersifat fleksibel artinya tindakan siap diubah sesuai kondisi yang ada sebagai usaha kearah perbaikan dan siklus akan dihentikan ketika indikator sudah tercapai. Guru sebagai pelaksana dan peneliti mengamati dan mengevaluasi. Pelaksanaan tindakan berpedoman pada RKH yang telah dipersiapkan oleh guru dan peneliti. Pelaksanaan tindakan dilaksanakan tiga tahap yaitu: kegiatan awal, kegiatan inti dan kegiatan akhir.

Peneliti mengobservasi perkembangan kognitif saat proses pembelajaran sedang berlangsung dan memberi skor pada butir amatan dengan menggunakan lembar observasi yang telah disusun. Hal-hal yang diamati peneliti mengenai mengenal sebab akibat tentang lingkungan, mengklasifikasi berdasarkan ukuran (mengenal besar kecil), konsep ukuran berat ringan dengan menggunakan timbangan, membilang hasil pancingan, mencocokkan bilangan dengan lambang bilangan. Selama observasi peneliti juga mendokumentasikan proses pembelajaran yang berlangsung, untuk mengetahui aktivitas anak selama pembelajaran

Refleksi untuk mengkaji semua tindakan yang telah dilaksanakan berdasarkan data yang telah terkumpul, dievaluasi bersama guru kelas untuk menyempurnakan tindakan selanjutnya. Kegiatan refleksi dilakukan setiap akhir kegiatan pembelajaran menggunakan media bermain memancing. Penelitian ini dilaksanakan pada bulan Desember 2015 sampai Mei 2016 bertempat di TK Miftahul Huda, Kabupaten Cilacap.

Subjek penelitian tindakan kelas ini anak kelompok Bı TK Miftahul Hudatahun pelajaran 2015/2016 berjumlah 23 anak (9 laki-laki dan 14 perempuan). Dipilih anak kelompok Bı karena dari hasil observasi dan wawancara perkembangan kognitif anak kelompok Bi belum maksimal.Dari 23 anak, 14 anak perkembangan kognitif belum maksimal dari aspek mengenal sebab akibat tentang lingkungan, membedakan konsep berat ringan, mengklasifikasikan benda berdasarkan ukuran, konsep bilangan, dan lambang bilangan.

\section{Teknik Dan Instrumen Pengumpulan Data}

Teknik pengumpulan data untuk memperoleh informasi data yang representif dan signifikan terhadap proses dan aktivitas pembelajaran serta situasi yang mempengaruhinya. Teknik pengumpulan data yang digunakan dalam penelitian ini adalah observasi, wawancara dan studi dokumentasi.

Pengumpulan data melalui observasi dilakukan peneliti dan guru kelas pada subjek penelitian saat proses pembelajaran berlangsung. Observasi yang dilakukan meliputi tentang proses pembelajaran kognitif menggunakan media bermain memancing yang berpedoman pada lembar observasi mengenai mengenal sebab akibat tentang lingkungan, membedakan konsep berat ringan, mengklasifikasikan benda berdasarkan ukuran, konsep bilangan dan lambang bilangan.

Wawancara dengan guru kelas dilaksanakan setelah melakukan pengamatan pertama untuk mendapatkan keterangan dan informasi melalui percakapan mengenai kendala selama proses pembelajaran. Studi dokumentasi berupa foto rekaman proses tindakan penelitian yaitu rekaman proses pembelajaran melalui media bermain memancing. 


\section{Jurnal Pendidikan dan Pemberdayaan Masyarakat, 3 (2), November 2016 - 212 Wulandari Retnaningrum}

Instrumen penelitian menggunakan lembar observasi dan lembar wawancara. Lembar observasi untuk mencatat hasil pengamatan yang dilakukan peneliti dengan guru dan memberi skor pada butir amatan mengenaimengenal sebab akibat tentang lingkungan, mengklasifikasi berdasarkan ukuran (besar kecil), konsep ukuran berat ringan menggunakan timbangan, membilang hasil pancingan, mencocokkan bilangan dengan lambang bilangan. Lembar wawancara untuk menggali data secara mendalam terhadap kebermaknaan hasil perkembangan kognitif melalui media bermain memancing menurut guru dan mengetahui kendalakendala selama proses pembelajaran melalui percakapan.

\section{Kriteria Keberhasilan Tindakan}

Kriteria merupakan patokan untuk menentukan keberhasilan suatu kegiatan. Sesuai dengan karakteristik penelitian tindakan, keberhasilan dalam penelitian apabila anak mengalami perubahan ke arah yang lebih baik dan adanya perubahan suasana pembelajaran melalui media bermain memancing dengan membandingkan hasil sebelum tindakan dengan sesudah tindakan.

Kriteria keberhasilan apabila ada perubahan kearah yang lebih baik yaitu adanya peningkatan perkembangan kognitif. Dimyati (2013, p.105) mengemukakan keberhasilan anak ditentukan kriterianya yakni $\geq 75 \%$, artinya anak dikatakan berhasil apabila mencapai $\geq 75 \%$ dari nilai yang harus dicapai, kurang dari tersebut dinyatakan kurang berhasil.Data diinterprestasikan ke dalam tiga tingkatan (a) Kriteria baik, apabila nilai yang diperoleh anak antara $75 \%$ 100\%. (b) Kriteria kurang baik, apabila nilai yang diperoleh anak antara $65 \%-75 \%$. (c) Kriteria tidak baik, apabila nilai yang diperoleh anak antara $45 \% 60 \%$.

Prosentase ini untuk mempertegas peningkatan perkembangan kognitif anak pada kondisi awal dan setelah peneliti melakukan tindakan. Selanjutnya ketuntasan atau keberhasilan anak terhadap siklusnya dideskripsikan melalui kata-kata atau kalimat secara menyeluruh pada subyek peneliti.

Analisis data dalam penelitian ini bersifat diskriptif kualitatif yaitu menggambar- kan kenyataan yang ada dan dijabarkan dalam bentuk narasi yang diperoleh dari lembar pengamatan. Data dijelaskan dalam bentuk analisis data kuantitatif untuk mengetahui peningkatan perkembangan kognitif anak sebagai akibat dari perlakuan yang diberikan guru. Tujuannya adalah untuk mengetahui peningkatan perkembangan kognitif melalui media bermain memancing.

$P=\frac{\mathrm{F}}{\mathrm{N}} \mathrm{X}_{100 \%}$

Keterangan:

$\mathrm{P}=$ Angka Persentase.

$\mathrm{N}=$ Jumlah anak

$\mathrm{F}=$ Frekuensi yang sedang dicari

persentasenya.

\section{HASIL DAN PEMBAHASAN}

Peneliti melihat hasil pra siklus yang dilakukan pada kelompok B1 TK Miftahul Huda, Kabupaten Cilacap tingkat pencapaian perkembangan kognitif anak usia 5-6 tahun mulai berkembang tetapi pada umumnya tingkat pencapaian perkembangan kognitif anak belum optimal. Proses kegiatan pembelajara masih berpusat pada guru, menggunakan LKA, hafalan dan belum menggunakan media. Hal ini memuat anak kurang antusias dan kurang tertarik mengerjakan tugas yang diberikan guru, belum ada interaksi antara anak dan guru, bahkan ada yang bermain sendiri, mengajak berbicara teman, menganggu teman dan keluar masuk ruangan sehingga situasi kelas menjadi tidak kondusif.

Hasil observasi perkembangan kognitif anak sebelum tindakan tersaji pada Tabel 1 dan Gambar 1.

Tabel 1. Pencapaian Perkembangan Kognitif Sebelum Tindakan

\begin{tabular}{clc}
\hline No & \multicolumn{1}{c}{$\begin{array}{c}\text { Indikator Perkembangan } \\
\text { Kognitif }\end{array}$} & Persentase \\
\hline 1. & $\begin{array}{l}\text { Mengenal sebab akibat } \\
\text { tentang lingkungan }\end{array}$ & $50,72 \%$ \\
2. & $\begin{array}{l}\text { Membedakan ukuran berat } \\
\text { ringan }\end{array}$ & $52,17 \%$ \\
3. & $\begin{array}{l}\text { Mengklasifikasi berdasarkan } \\
\text { ukuran }\end{array}$ & $59,42 \%$ \\
4. & $\begin{array}{l}\text { Membilang 1-10 } \\
\text { Mencocokkan bilangan } \\
\text { dengan lambang bilangan }\end{array}$ & $62,32 \%$ \\
\hline Rata-rata ketercapaian anak & $58,55 \%$ \\
\hline
\end{tabular}




\section{Jurnal Pendidikan dan Pemberdayaan Masyarakat, 3 (2), November 2016 - 213}

Wulandari Retnaningrum

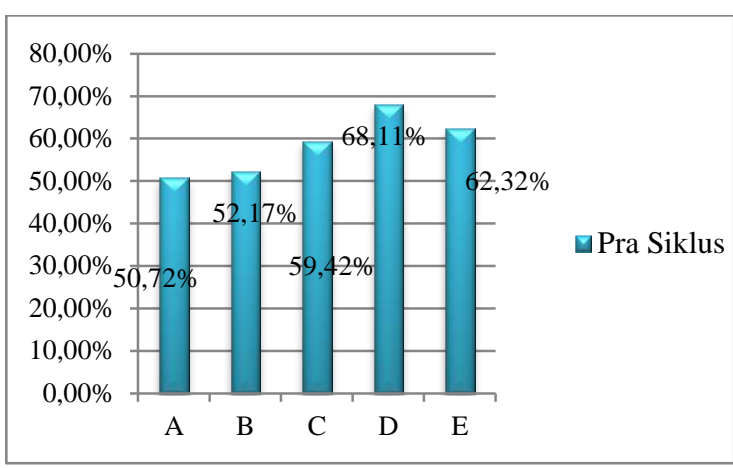

Gambar 1. Diagram Pencapaian

Perkembangan Kognitif Sebelum Tindakan

Keterangan :

A: Mengenal sebab akibat tentang lingkungan.

B: Membedakan ukuran berat ringan.

C: Mengklasifikasi berdasarkan ukuran.

D: Membilang 1-10.

E: Mencocokkan bilangan dengan lambang bilangan.

Berdasarkan Tabel 1 dan Gambar 1 dapat disimpulkan bahwa perkembangan kognitif anak kelompok B1 TK Miftahul Huda, Kabupaten Cilacap pada umumnya belum berkembang secara optimal. Data tersebut menunjukkan perkembangan kognitif anak masih dalam kategori mulai berkembang, anak baru mampu melakukan beberapa kegiatan pembelajaran yang mengembangkan aspek kognitif dan masih memerlukan stimulasi untuk mengembangkan aspek kognitif lebih lanjut. Perlu adanya perbaikan untuk meningkatkan perkembangan kognitif anak dalam proses pembelajaran yang lebih menarik, kreatif dan inovatif melalui media bermain memancing yang akan dilaksanakan pada siklus I.

\section{Siklus I}

Pelaksanaan tindakan penelitian menggunaan media bermain memancing siklus I pada tanggal 5 sampai 11 Februari 2016 dengan alokasi waktu pembelajaran 150 menit. Peneliti berkolaborasi dengan guru kelas kelompok B1 sebagai pengajar dan peneliti sebagai pengamat yang mengamati secara langsung dan merekam proses kegiatan pembelajaran menggunakan media bermain memancing.

Tahap perencanaan pembelajaran dituangkan secara tertulis dalam bentuk Rencana Kegiatan Harian (RKH) dan menyiapkan media bermain memancing supaya proses pembelajaran lebih menarik, menyenangkan, anak terlibat dan mendapatkan pengalaman langsung saat pembelajaran.

Indikator pencapaian perkembangan kognitif anak yang harus dicapai dalam pembelajaran menggunakan media bermain memancing dengan tema wisata di kota Cilacap dan sub tema pantai teluk penyu dan pemancingan ikan pada pelaksanaan siklus I yaitu (a) Anak dapat mengenal sebab akibat tentang lingkungan (akibat ikan makan umpan di kail saat dipancing; ikan akan mati setelah dipancing jika tidak berada di air;ikan bernafas menggunakan insang maka ikan hidup di air, bila ikan berada di darat ikan menjadi mati), (b) Anak dapat membedakan ukuran berat ringan, (c) Anak dapat mengklasifikasi berdasarkan ukuran, (d) Anak dapat membilang, (e) Anak dapat mencocokkan bilangan dengan lambang bilangan.

Kegiatan siklus I telah sesuai dengan RKH. Proses kegiatan pembelajaran: (a) guru berinteraksi dengan anak berhubungan dengan mengenal sebab akibat, (b) guru memperlihatkan dan menjelaskan media memancing yang akan digunakan, (c) anak bermain memancing ikan-ikanan. Hasil pancingan di klasifikasi antara ikan-ikanan yang besar dan yang kecil kemudian ditimbang untuk mengetahui berat ringan, menghitung jumlah ikan yang besar dan ikan yang kecil kemudian mengambil kartu angka sesuai dengan jumlah hitungan.

Perkembangan kognitif anak pada siklus I mengalami peningkatan walaupun target penelitian belum tercapai. Hal ini ditunjukkan dengan perkembangan kognitif anak sesuai dengan indikator perkembangan yang telah ditetapkan pada umumnya belum berkembang secara optimal. Ketercapaian perkembangan kognitif anak yang belum optimal pada indikator mengenal sebab akibat tentang lingkungan, membedakan ukuran berat ringan dan mencocokan bilangan dengan lambang bilangan.Ketercapaian perkembangan kognitif anak dikatakan berkembang pada indikator mengklasifikasi berdasarkan ukuran dan membilang '1-10.2 anak masih dalam kategori mulai berkembang, 14 anak berkembang sesuai harapan dan 7 anak berkembang sangat baik. Dari data tersebut 


\section{Jurnal Pendidikan dan Pemberdayaan Masyarakat, 3 (2), November 2016 - 214}

Wulandari Retnaningrum

tampak ada peningkatan perkembangan kognitif anak dibandingkan dengan data perkembangan kognitif sebelum menggunakan media bermain memancing. Hasil pencapaian perkembangan kognitif anak siklus I tersaji pada Tabel 2 dan Gambar 2.

Tabel 2. Hasil Pencapaian Perkembangan Kognitif Anak Siklus I

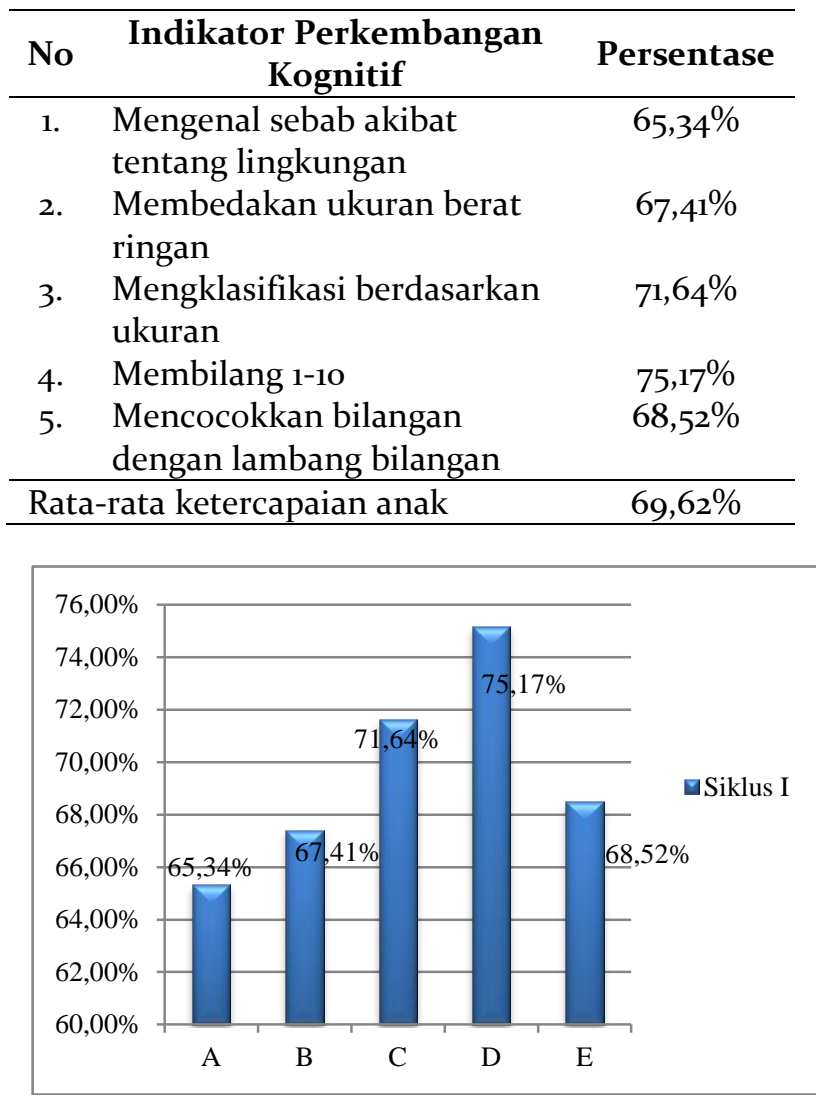

Gambar 2. Diagram Pencapaian Perkembangan Kognitif Sebelum Tindakan

Keterangan :

A: Mengenal sebab akibat tentang lingkungan.

B: Membedakan ukuran berat ringan.

C: Mengklasifikasi berdasarkan ukuran.

D: Membilang 1-10.

E: Mencocokkan bilangan dengan lambang bilangan.

Penggunaan media bermain memancing membuat anak senang, antusias dan tertarik saat proses pembelajaran, walaupun masih ada kekurangan-kekurangan sehingga hasil yang diperoleh belum tercapai secara optimal. Kekurangan-kekurangan yang ditemukan antara lain: (1) Media memancing baru pertama kali digunakan sehingga saat guru menjelaskan dan memberi contoh belum semua anak melakukan interaksi dengan guru; (2) Guru belum sepenuhnya memberikan bimbing, rangsangan dan langsung memberitahu pada anak yang belum mampu; (3) Suasana kelas belum terkondisikan karena anak yang sudah menyelesaikan semua kegiatan diberi kebebasan untuk bermain sendiri tanpa diarahkan guru, mengajak teman mengobrol, keluar masuk ruangan, bermain sendiri dan menganggu teman.

Hasil dari refleksi dan rencana perbaikan tindakan yang dilakukan guru kelas dan peneliti sebagai acuan untuk memperbaiki hasil pada siklus II sehingga hasil yang dicapai lebih maksimal untuk meningkatkan perkembangan kognitif sesuai dengan tahapan perkembangan dapat tercapai secara optimal.

\section{Siklus II}

Siklus II merupakan tindak lanjut siklus I. Siklus II dilaksanakan pada tanggal 22 sampai 26 Februari 2016. Pelaksanaan siklus II sesuai dengan RKH dan skenario yang telah dibuat berdasarkan refleksi siklus I. Perencanaan proses pembelajaran dilakukan kembali dengan memperhatikan kekurangan yang terjadi pada siklus I yang telah direfleksi peneliti dengan guru kelas sehingga dapat memperbaiki kekurangan yang terjadi pada siklus I sebelum melaksanakan tindakan di siklus II. Peneliti melakukan perbaikan pada siklus II antara lain: (1) tempat bermain memancing dilaksanakan di luar kelas supaya anak tidak merasa bosan bila belajar di dalam kelas, (2) pengkondisian kelas dengan memberikan kegiatan yang terarah pada anak yang telah menyelesaikan kegiatan. Misalnya bermain balok, puzzle, mewarnai gambar dengan pengawasan dari guru, (3) guru melakukan interaksi dengan anak, (4) guru memberikan bimbingan dan rangsangan pada anak yang belum mampu mengerjakan tugas.

Indikator pencapaian perkembangan kognitif anak yang harus dicapai dalam pembelajaran menggunakan media pada pelaksanaan siklus II yaitu: (a) Anak dapat mengenal sebab akibat tentang lingkungan (air ikan di aquarium tidak diganti menyebabkan air ikan menjadi keruh; ikan tidak cepat besar bila tidak diberi makan sesuai aturan; 


\section{Jurnal Pendidikan dan Pemberdayaan Masyarakat, 3 (2), November 2016 - 215}

Wulandari Retnaningrum

ikan akan lapar dan mati bila tidak diberi makan), (b) Anak dapat membedakan ukuran berat ringan, (c) Anak dapat mengklasifikasi berdasarkan ukuran, (d) Anak dapat membilang, (e) Anak dapat mencocokkan bilangan dengan lambang bilangan.

Perencanaan pembelajaran dituangkan secara tertulis dalam bentuk Rencana Kegiatan Harian (RKH) supaya hasil yang diperoleh lebih baik dari siklus I. Rencana pembelajaran siklus II menggunakan tema binatang dan sub tema binatang air. Kegiatan pembelajaran siklus II menggunakan media bermain memancing dengan persiapan yang lebih baik berdasarkan pengalaman pada siklus I.

Proses kegiatan pembelajaran siklus II: (a) guru berinteraksi dengan anak berhubungan dengan mengenal sebab akibat, (b) guru memperlihatkan dan menjelaskan media memancing yang akan digunakan, (c) anak bermain memancing ikan-ikanan. Hasil pancingan di klasifikasi antara ikan-ikanan yang besar dan yang kecil kemudian ditimbang untuk mengetahui berat ringan, menghitung jumlah ikan yang besar dan ikan yang kecil kemudian mengambil kartu angka sesuai dengan jumlah hitungan.

Setelah melaksanakan kegiatan pembelajaran siklus II, peneliti bersama guru kelas melakukan refleksi berdasarkan hasil observasi aktivitas anak selama proses pembelajaran berlangsung untuk mengetahui sejauh mana keberhasilan pembelajaran menggunakan media bermain memancing. Hasil refleksi siklus II terlihat kegiatan pembelajaran siklus II menunjukkan keadaan yang lebih baik, lebih lancar sesuai rencana dan suasana kelas lebih kondusif, anak terlihat lebih aktif dan tertib, tidak ada anak bermain sendiri, berbicara dengan teman, menganggu teman saat mengikuti proses kegiatan pembelajaran menggunakan media bermain memancing.

Hasil penelitian siklus II menunjukkan adanya peningkatan perkembangan kognitif anak yang signifikan jika dibandingkan dengan kondisi awal sebelum tindakan dan sesudah pelaksanaan siklus I karena anak sudah terbiasa menggunakan media bermain memancing saat kegiatan pembelajaran,anak sudah berinteraksi dengan guru saat tanya jawab mengenal sebab akibat tentang lingkungan, sudah mampu membedakan berat ringan, mengklasifikasi benda berdasarkan ukuran, memahami bilangan dan lambang bilangan.

Hasil observasi perkembangan kognitif siklus II disajikan Tabel 3 dan Gambar 3.

\section{Tabel 3. Hasil Perkembangan Kognitif Anak} Siklus II

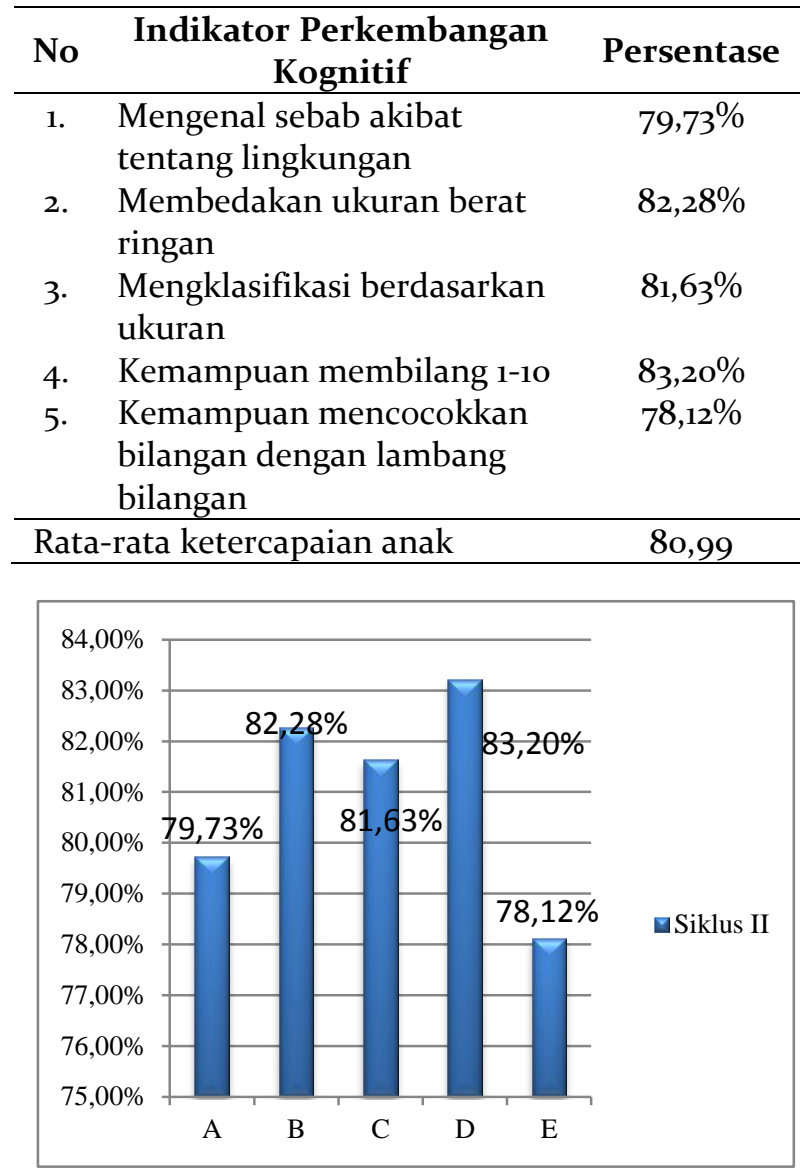

Gambar 3. Diagram Pencapaian Perkembangan Kognitif Siklus II

Keterangan:

A: Mengenal sebab akibat tentang lingkungan.

$\mathrm{B}$ : Membedakan ukuran berat ringan.

C: Mengklasifikasi berdasarkan ukuran.

D: Membilang 1-10.

E: Mencocokkan bilangan dengan lambang bilangan.

Berdasarkan Tabel 3 dan Gambar 3, pencapaian indikator perkembangan kognitif anak menggunakan media bermain memancing berkembang sangat baik, masalah dan kelemahan yang ditemui pada siklus I sudah dapat teratasi. Setiap indikator mengalami tingkat ketercapaian. Secara umum 16 anak berkembang sangat baik, 5 anak ber- 


\section{Jurnal Pendidikan dan Pemberdayaan Masyarakat, 3 (2), November 2016 - 216 Wulandari Retnaningrum}

kembang sesuai harapan dan 2 anak mulai berkembang disebabkan sering tidak masuk karena sakit.

Hasil perkembangan kognitif anak siklus II sebagai berikut: (a) Mengenal sebab akibat tentang lingkungan mencapai $79,73 \%$ atau kriteria baik. Secara umum anak sudah memahami sebab akibat yang terjadi di lingkungan karena sudah ada interaksi tanya jawab antara guru dan anak dan anak lebih aktif dalam pembelajaran, tidak hanya menerima informasi dari guru tanpa mengembangkan pengalaman yang pernah dialami sebelumnya; (b)Membedakan ukuran berat ringan mencapai 82,28\% atau kriteria baik. Anak lebih memahami dan mengetahui perbedaan letak benda yang lebih berat atau lebih ringan meskipun masih ada 2 anak belum mampu membedakan ukuran berat dan ringan karena sering tidak masuk sekolah (sakit); (c) Mengklasifikasi berdasarkan ukuran mencapai 81,63\% atau kriteria baik. Anak terlibat aktif sehingga lebih memahami dan tidak mengalami kesulitan mengklasifi- kasi. 5 anak memerlukan sedikit bimbingan karena kurang teliti dan tergesa-gesa dalam bermain sehingga terjadi kekeliruan meletakkan antara yang besar dan kecil; (d) Membilang 1-10 mencapai 83,20\% atau kriteria baik karena pembelajaran sudah menggunakan media dan tidak hafalan sehingga anak tidak mengalami kesulitan dalam membilang 5 anak sedikit membutuhkan bimbingan dari guru karena anak kurang teliti, media yang kecil letaknya berada di bawah media yang lebih besar sehingga tidak terhitung; (e) Mencocokkan bilangan dengan lambang bilangan mencapai 79,12\% atau kriteria baik karena anak lebih memahami lambang bilangan dengan cara bermain menggunakan kartu angka dibandingkan dengan menulis di buku. Ada 9 anak memerlukan bimbingan guru karena terbalik antara angka 6 dan 9, menunjukkan angka 4 posisi letaknya terbalik. Rata-rata pencapaian perkembangan kognitif anak tersaji pada Tabel 4 dan Gambar 4.

Tabel 4. Hasil Persentase Perkembangan Kognitif Sebelum Tindakan, Siklus I dan II

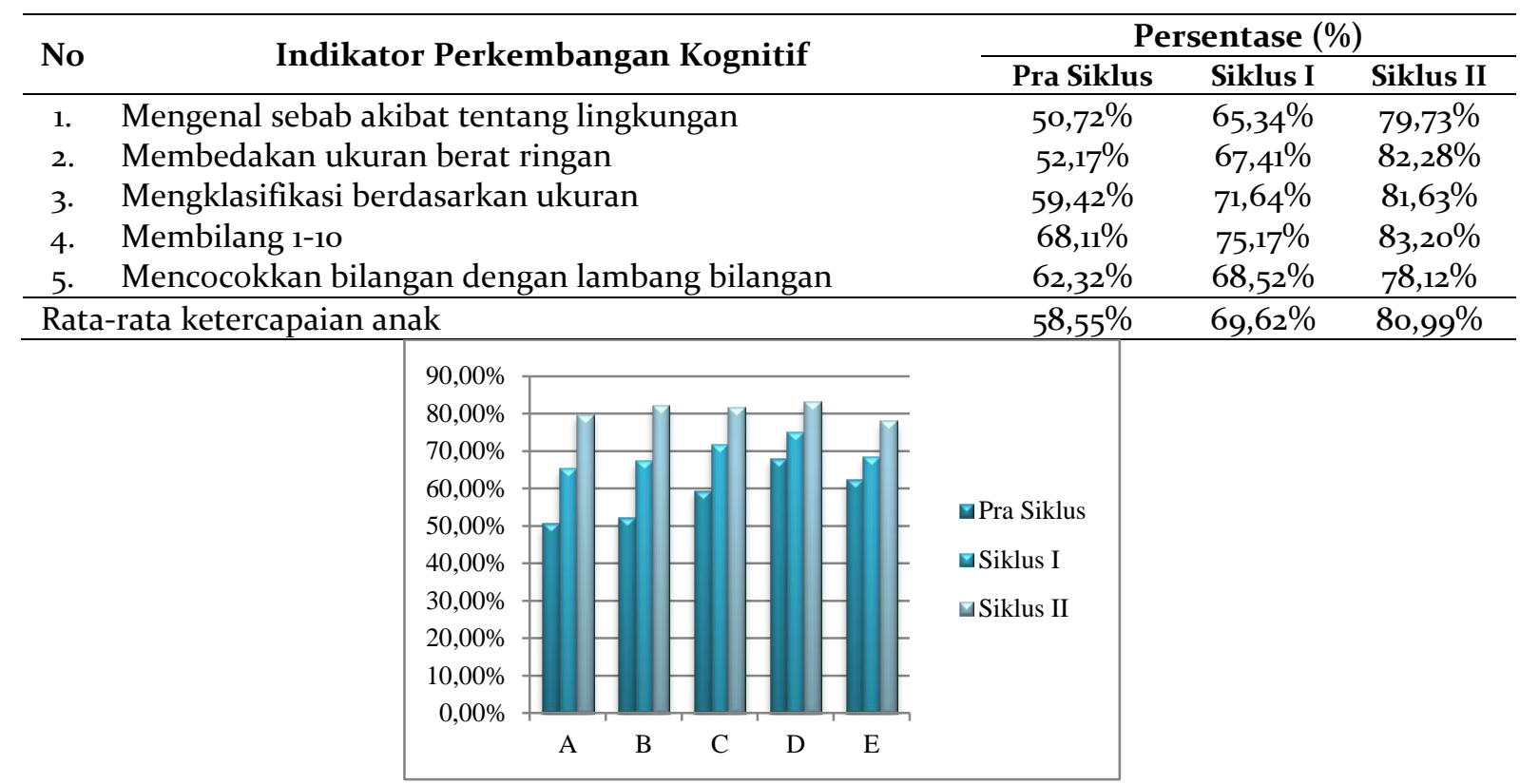

Gambar 4. Diagram Pencapaian Perkembangan Kognitif Sebelum Tindakan, Siklus I dan Siklus II.

Keterangan:

A : Mengenal sebab akibat tentang lingkungan

$\mathrm{B}$ : Membedakan ukuran berat ringan.

C : Mengklasifikasi berdasarkan ukuran.

D : Membilang 1-10.

E: Mencocokkan bilangan dengan lambang bilangan. 


\section{Jurnal Pendidikan dan Pemberdayaan Masyarakat, 3 (2), November 2016 - 217 \\ Wulandari Retnaningrum}

Perbandingan peningkatan perkembangan kognitif pra siklus, siklus I, dan siklus II tersaji pada Gambar 5.

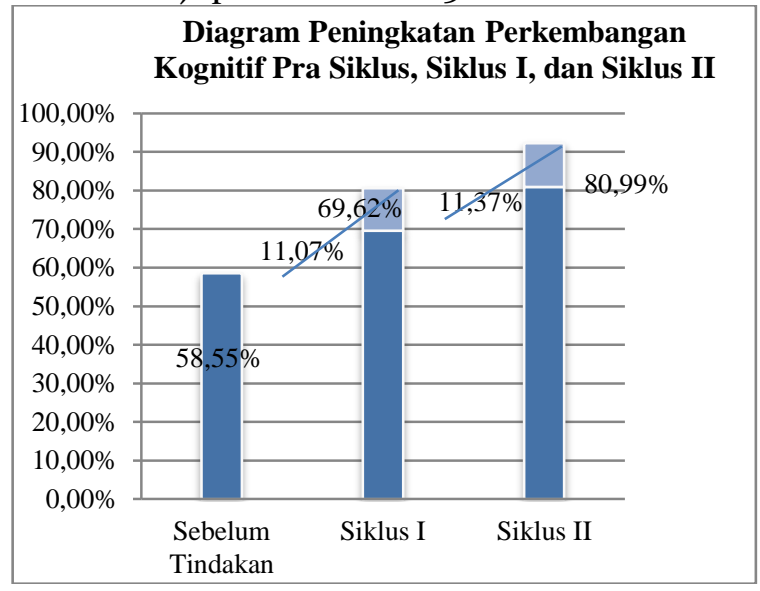

Gambar 5. Diagram Peningkatan

Perkembangan Kognitif Sebelum Tindakan

ke Siklus I dan dari Siklus I ke Siklus II.

Tabel 4 dan Gambar 5 menunjukan peningkatan perkembangan kognitif menggunakan media bermain memancing sebelum tindakan, siklus I, dan siklus II memperoleh kriteria baik. Sebelum tindakan persentase pencapaian perkembangan kognitf mencapai $58,55 \%$. Siklus I perkembangan kognitif meningkat menjadi $69,62 \%$, sehingga persentase peningkatan antara sebelum tindakan dan siklus I yaitu 11,07\%. Siklus II terjadi peningkatan perkembangan kognitif mencapai 8o,99\%. Peningkatan persentase perkembangan kognitif antara siklus I dan siklus II yaitu $11,37 \%$.

Hal ini membuktikan proses kegiatan pembelajaran menggunakan media bermain memancing merupakan hal yang baik untuk dilakukan karena hasil yang diperoleh berdasarkan teori dan penelitian dapat meningkatkan perkembangan kognitif anak sesuai tahapan perkembangan bila dibandingkan proses kegiatan pembelajaran dengan menggunakan LKA, bersifat hafalan dan belum menggunakan media. Pengunaan media bermain memancing dalam proses kegiatan pembelajaran sebagai upaya meningkatkan motivasi keingintahuan dan pemahaman anak dalam mengenal sebab akibat tentang lingkungan, mengembangkan konsep jumlah, memasangkan jumlah dengan lambang bilangan, memilih dan mengelompokkan benda-benda yang mempunyai kesamaan, mengembangkan keterampilan membandingkan sesuai ukuran dan bentuk menjadi menyenangkan dan menarik karena dengan menggunakan media bermain memancing anak merasa sedang bermain bukan sedang belajar. Guru harus melibatkan anak secara fisik dan mental dalam berpikir reflektif dengan membimbing, memotivasi dan memberikan rangsangan kepada anak agar dapat melakukan percobaan, memahami sesuatu, membangun pengertian sendiri dan menemukan pengalaman yang bermakna sehingga pengalaman dan pengetahuan anak dapat diintegrasikan dalam kehidupan nyata serta potensi yang dimiliki anak dapat berkembang secara optimal dan lebih baik serta mencapai indikator yang telah ditetapkan.

\section{SIMPULAN DAN SARAN}

\section{Simpulan}

Proses pembelajaran menggunakan media bermain memancing yaitu: (1) Guru berinteraksi untuk mengetahui kemampuan anak mengenal sebab akibat tentang lingkungan, (2) Anak bermain memancing, hasil pancingan diklasifikasi dan ditimbang kemudian dihitung berapa jumlah ikan-ikanan yang besar dan yang kecil, mengambil kartu angka untuk mencocokan bilangan dengan lambang bilangan. Pembelajaran melalui bermain memancing akan (a) mendorong rasa ingin tahu tentang apa yang anak lihat, dengar dan rasakan, (b) pembelajaran yang menjemukan dan membosankan akan hilang, (c) anak terlibat secara langsung dan aktif menemukan pengalaman untuk mengintegrasikan dalam kehidupan nyata, (d) anak dapat melakukan percobaan, memahami sesuatu, membangun pengertian sendiri dan menemukan pengalaman yang bermakna, (e) mengenal hubungan sebab akibat, membedakan konsep berat ringan, mengklasifikasikan benda berdasarkan ukuran, mengenal konsep bilangan dan lambang bilangan.

Perkembangan kognitif anak di TK Miftahul Huda Kabupaten Cilacap dapat ditingkatkan melalui media bermain memancing. Hal tersebut dapat dilihat dari peningkatan yang dialami dalam penelitian yang dilakukan peneliti dari sebelum 
tindakan, siklus I dan siklus II. Hasil penelitian menunjukkan bahwa perkembangan kognitif anak di setiap indikator dapat meningkat setelah melakukan tindakan. Peningkatan perkembangan kognitif anak sebelum tindakan dalam kategori mulai berkembang yaitu mencapai $58,55 \%$. Pada siklus I terjadi peningkatan sehingga menjadi $69,62 \%$ dalam kategori berkembang. Pada siklus II meningkat lagi menjadi 80,99\% dalam kategori sangat berkembang.

\section{Saran}

Guru hendaknya dalam kegiatan pembelajaran menggunakan media pembelajaran yang tepat, menarik, menyenangkan dan bervariasi agar anak tertarik, berminat dan antusias saat kegiatan pembelajaran; guru hendaknya dalam kegiatan pembelajaran melakukan interaksi dan melibatkan anak secara optimal pada kegiatan nyata agar anak mendapatkan pengalaman langsung dari proses pembelajaran; guru sebaiknya melanjutkan menggunakan media yang telah digunakan saat peneliti melakukan penelitian dalam proses pembelajaran untuk meningkatkan perkembangan kognitif anak.

Penelitian yang serupa dilakukan peneliti berikutnya hendaknya menggunakan pendekatan dan materi yang berbeda.

\section{DAFTAR PUSTAKA}

Benson, A., \& Odera, F. (2013). Selection and use of media in teaching Kiswahili language in secondary schools in Kenya. International Journal of Information and Communication Technology Research. Vol. 3, No. 1, Januari 2013. Diakses tanggal 20 Desember 2015.

Bernard, S \& Olivia, N.S. (1994). Right from the start: Teaching children ages three to eight. Boston: Allyn and Bocon.
Brewer, J.A. (2007). Introduction to early childhood education. Boston: Pearson Allyn and Bacon.

Dimyati, J. (2013). Metodologi penelitian pendidikan dan aplikasinya pada PAUD. Bandung: Kencana.

Goldstein, J. (2012). Play in children's development, health and well-being. Utrecht: Utrecht University.

Ikatan Guru Taman Kanak-Kanak Indonesia Kabupaten Cilacap (2015). Pedoman pengembangan kurikulum 2013 PAUD taman kanak-kanak.

Mena, J.G., \& Eyer, D.W. (2009). Infants, toddlers, and caregivers. New York, NY: McGraw-Hill.

Mulyasa. H.E (2014). Manajemen PAUD. Bandung: PT Remaja Rosdakarya.

Feldman, P. O. (2009). Human development perkembangan manusia edisi 10. (Alih bahasa: Brian Marswendy). Jakarta: Salemba Humanika.

Huang, R (2013). What can children learn through play? Chinese parents' perspective of play and learning in early childhood education. School of Education Journal. Vol. 1 No. 1. Diakses tanggal 18 Agustus 2016.

Santrock, J.W. (2007). Perkembangan anak jilid 1 (child development) (alih bahasa: Mila Rahmawati \& Anna Kuswanti). Jakarta : Erlangga.

Sujiono, Y.N. (2014). Metode pengembangan kognitif. Tangerang Selatan: Universitas Terbuka.

Pusat Kurikulum Direktorat Pendidikan Anak Usia Dini Universitas Negeri Jakarta. (2007). Kerangka dasar pendidikan anak usia dini. Departemen Pendidikan Nasional.

Wijaya, W.D. (2009) Kurikulum pendidikan anak usia dini. Jakarta: Universitas Terbuka. 